\begin{abstract}
Iranica
Abstracta Iranica Revue bibliographique pour le domaine irano-aryen

Volume 34-35-36 | 2017

Comptes rendus des publications de 2011-2013
\end{abstract}

\title{
Florence Jullien. Stratégies du monachisme missionnaire chrétien en Iran
}

\section{Marie-Joseph Pierre}

\section{Q OpenEdition}

10 Journals

\section{Édition électronique}

URL : http://journals.openedition.org/abstractairanica/41926

DOI : 10.4000/abstractairanica.41926

ISSN : 1961-960X

Éditeur :

CNRS (UMR 7528 Mondes iraniens et indiens), Éditions de l'IFRI

\section{Référence électronique}

Marie-Joseph Pierre, «Florence Jullien. Stratégies du monachisme missionnaire chrétien en Iran », Abstracta Iranica [En ligne], Volume 34-35-36 | 2017, document 20, mis en ligne le 30 décembre 2016, consulté le 27 septembre 2020. URL : http://journals.openedition.org/abstractairanica/41926 ; DOI : https://doi.org/10.4000/abstractairanica.41926

Ce document a été généré automatiquement le 27 septembre 2020.

Tous droits réservés 


\section{Florence Jullien. Stratégies du monachisme missionnaire chrétien en Iran}

Marie-Joseph Pierre

\section{RÉFÉRENCE}

Florence Jullien. «Stratégies du monachisme missionnaire chrétien en Iran », in : C. Jullien, éd., Itinéraires missionnaires. Échanges et identités. Paris, AAEI - Peeters, 2011, p. 49-69. (St. Ir. Cahier 44 : Chrétiens en terre d'Iran, IV)

1 Si les moines syro-occidentaux comme syro-orientaux jouèrent un rôle essentiel dans l'expansion du christianisme en Iran, on peut également dire que cette dynamique missionnaire fut corrélative au développement de la structure monastique elle-même. Cet article s'intéresse aux techniques de pénétration de ce monachisme missionnaire chrétien, mettant en valeur ses stratégies d'approche. Il montre la coordination étroite entre mission et formation en soulignant l'importance de la fondation d'écoles associées, mais aussi l'insertion de ces missions dans le cadre de réseaux monastiques.

\section{AUTEURS}

MARIE-JOSEPH PIERRE

Directrice d'Études honoraire, EPHE 